\title{
Further Studies on the Effect of Niridazole on Urinary and Biliary Excretion of Copper
}

\author{
By F. T. Abdel Aziz, Z. M. Abdallah and Z. A. Hassan \\ Biochemistry Dept., Faculty of Pharmacy and Medicine, Zagazig University, Zagazig, Egypt
}

(Received April 14/December 17, 1982)

Summary: Administration of niridazole to rats poisoned with copper caused a significant increase in both the urinary and biliary excretion of the metal. Although the urinary excretion of iron was increased by the drug, iron excretion was significantly decreased during the drug-induced excretion of copper after copper poisoning. Formation of a copper-niridazole chelate or chelates before excretion, in the bile or urine may explain these findings. Polarity and molecular weights of the metal-drug chelates formed in vivo may be the directing forces not only in the selection of the metal for chelation, but also for its urinary or biliary excretion. The laboratory preparation of two copper-niridazole complexes lends support to these conclusions.

\section{Weitere Untersuchungen zur Wirkung von Niridazol auf die Ausscheidung von Kupfer in Harn und Galle}

Zusammenfassung: Niridazol steigert bei mit Kupfer vergifteten Ratten die Kupferausscheidung in Harn und Galle signifikant. Obwohl die Eisenausscheidung im Harn durch Niridazol gesteigert war, war sie während der durch Niridazol induzierten Ausscheidung von Kupfer nach Kupfervergiftung signifikant erniedrigt. Bildung von Kupferchelat(en) vor der Ausscheidung mit Galle oder Harn kann diese Beobachtungen erklären. Polarität und Molekulargewichte der in vivo gebildeten Metallchelate können Einflußgrößen nicht nur für die Selektion des Metalls für die Chelatbildung, sondern auch für seine Ausscheidung mit Harn oder Galle sein.

Die Präparation von zwei Kupfer-Niridazolkomplexen im Laboratorium unterstützt unsere Schlußfolgerungen.

\section{Introduction}

In earlier studies, the antibilharzial drug, niridazole (ambilhar), was shown to have the property of ligating or chelating iron. Salah et al. (1) and Abdel Aziz et al. (2) demonstrated the excretion of iron in the urine of man and animals during administration of the drug. Similar effects of niridazole on body calcium and magnesium (3) and lead (4) were reported. The later findings on lead excretion were explained by the formation of a lead-niridazole complex in vivo, which resulted in lead mobilization and excretion.

Later, Abdel Aziz et al. (5) reported that niridazole stimulated the biliary excretion of mercury in rats.
This finding was explained by the formation of a polar complex with mercury of a higher molecular weight, which undergoes biliary rather than urinary excretion.

$D$-Penicillamine is an orally administered chelating agent used mainly in Wilson's disease. It increases the urinary output of copper more than 5 times compared with that of untreated cases. It was found that $D$-penicillamine gives rise to some undesirable effects (6).

The aim of this study is to investigate the effect of niridazole on the excretion of copper, which could be useful clinically in copper storage diseases. Also the effect of niridazole on body iron excretion under these conditions seems important. 


\section{Materials and Methods}

In vivo experiments

A total of 18 Wistar albino rats, average weight $200-250 \mathrm{~g}$ were used for this study. They were fed a commercial diet prepared in the College animal house.

The animals were classified into three equal groups of 6 animals. Group A were used as control, while group B were dosed with niridazole orally in a dose level of $5 \mathrm{mg} / \mathrm{d}$. Group $C$ animals were poisoned with copper. A total daily dose of $4 \mathrm{mg}$ copper was administered orally to each animal for 7 successive days.

Administration of niridazole after copper poisoning

Ambilhar (niridazole or nitrothiazole) was mixed with two kilograms of the same diet. so that each gram contained about $0.5 \mathrm{mg}$ of the drug.

Administration of the drug was continued for 7 days, starting just after the last day of copper poisoning. The urine and faecal matter of each group was separately collected for analysis of iron and copper.

Estimation of the copper and iron contents of urine and faeces

A suitable weight of the dried faecal matter $(5 \mathrm{~g})$ of each group was pulverized in a morter with $5 \mathrm{ml}(300 \mathrm{~g} / \mathrm{kg}) \mathrm{HCl}$ (analar), then gently heated over a direct flame for 30 minutes at $100^{\circ} \mathrm{C}$. It was left to cool for 24 hours at $4^{\circ} \mathrm{C}$. Filtration gave a clear filtrate. which used for the analysis. Using this filtrate or $5 \mathrm{ml}$ urine, copper and iron were measured with the atomic absorption spectrophotometer (Perkin-Elmer 503) (7).

A standard solution of copper and iron containing $5 \mathrm{mg} /$ of each was prepared. A working standard solution was prepared by mixing equal volumes of both standards.

Serial dilutions of this working standard containing $2.5,5,7.5,10$ and $12.5 \mu \mathrm{g}$ were used for preparing the standard curve.

In vitro experiments

To three equal fractions ( $1 \mathrm{mmol}$ each $=214 \mathrm{mg}$ ) of pure crystalline niridazole (Ciba-Geigy product) in three separate beakers 0.5. 1 and $2 \mathrm{mmol}$ copper were added respectively (anhydrous copper carbonate, BDH). To each beaker 2 grams sodium metabisulphite (BDH) and $25 \mathrm{ml}$ distilled water were added. The whole mixture was left for 48 hours at $70^{\circ} \mathrm{C}$ in an oven. A dark crystalline compound was precipitated. This was filtered, washed with ethanol $(900 \mathrm{ml} / \mathrm{l})$ followed by distilled water (three times $5 \mathrm{ml}$ each), then crystallized from hot glacial acetic acid. Paper chromatography of the acetic acid solution of the second and third fractions (solvent system: methanol-acetic acid, $6+1$ by vol.) showed one spot from each fraction, $R_{r} 0.3$ and 0.5 respectively. About $10 \mathrm{mg}$ samples of each of these two fractions were submitted for determination of molecular weights and copper contents. The results are shown in table 2.

\section{Results and Discussion}

It is clear from table 1 that the urinary excretion of copper during administration of niridazole is significantly incrased. This finding can be explained by a possible chelation of the drug with copper followed by excretion. Evidence for such chelation is found in previous studies on the effect of the drug on excretion of other metals by chelation (1-4). Also iron excretion was significantly increased under these conditions.

Unlike iron, copper was also excreted in the bile as well as the urine. However, the major route for its excretion during drug administration was found to be urinary. It is also clear that in niridazole-treated animals after poisoning with copper, there is a biliary excretion of copper amounting to $50 \%$ of that excreted in the urine. This finding can be explained by the higher molecular weight of the drug-copper complex formed in vivo $(8,9)$, which undergoes biliary excretion. Preparation in vitro of two niridazolecopper complexes with different molecular weights could be evidence for similar in vivo metabolic behaviour. Under these conditions one of the complexes (higher molecular weight) undergoes biliary excretion, while the other (lower molecular weight) is excreted in the urine.

The same table shows a relationship between copper and iron excretion. Increased copper excretion by the drug was accompanied by a significant decrease of iron excretion i.e., in niridazole-treated animals after intoxication with copper, the reduction in urinary iron excretion was about $50 \%$, and the decrease in biliary iron excretion was found to be about $13 \%$.

The metabolic behaviour of both copper and iron is affected by the drug. Before poisoning with copper the drug caused a significant decrease in copper biliary excretion with a concomitant increase in its urinary output. After poisoning with copper the drug increased the biliary excretion of copper significant-

Tab. 1. Effect of niridazole on the urinary and biliary excretion of copper and iron in Wistar albino rats (mg/week).

\begin{tabular}{|c|c|c|c|c|}
\hline \multirow[t]{2}{*}{ Group of rats } & \multicolumn{2}{|c|}{ Copper } & \multicolumn{2}{|c|}{ Iron } \\
\hline & Urine & Bile & Urine & Bile \\
\hline 1. Control animals & $\begin{array}{r}0.039 \\
\pm(0.001)\end{array}$ & $\begin{array}{r}0.292 \\
\pm(0.016)\end{array}$ & $\begin{array}{c}0.337 \\
\pm(0.014)\end{array}$ & $\begin{array}{r}0.490 \\
\pm(0.017)\end{array}$ \\
\hline 2. Niridazole dosed animals & $\begin{aligned} & 0.073^{* *} \\
& \pm(0.005)\end{aligned}$ & $\begin{array}{l}0.051^{* *} \\
\pm(0.003)\end{array}$ & $\begin{array}{l}0.962^{* *} \\
\pm(0.12)\end{array}$ & $\therefore \quad \begin{aligned} & 0.238^{* *} \\
\pm & (0.011)\end{aligned}$ \\
\hline 3. Niridazole dosed animals after poisoning with copper & $\begin{aligned} & 0.756^{* *} \\
\pm & (0.05)\end{aligned}$ & $\begin{array}{l}0.371^{* *} \\
\pm(0.01)\end{array}$ & $\begin{aligned} & 0.467^{* *} \\
& \pm(0.055)\end{aligned}$ & $\begin{array}{r}0.282^{* *} \\
\pm(0.015)\end{array}$ \\
\hline
\end{tabular}

\footnotetext{
* Significant at $5 \%$ probability.
}

** Significant at $1 \%$ probability. 
ly. Under these conditions the drug caused a marked decrease in biliary excretion of iron, which can be explained by the higher chelating power of niridazole for copper than for iron (in vivo), forming a higher molecular weight complex which undergoes biliary excretion $(8,9)$. Table 2 shows the results of our in vitro experiments.

Tab. 2. Copper content, molccular weight and chelation ratio of the two copper-niridazole complexes prepared in vitro.

\begin{tabular}{llll}
\hline Complex & $\begin{array}{l}\text { Copper } \\
\text { (fraction) }\end{array}$ & $\begin{array}{l}\text { Molecular } \\
\text { weight }\end{array}$ & $\begin{array}{l}\text { Chelation ratio } \\
\text { copper: niridazole }\end{array}$ \\
\hline Complex 1 & 0.2545 & 249.5 & $1: 1$ \\
Complex 2 & $0.4(183$ & 311 & $2: 1$ \\
\hline
\end{tabular}

Finally, this study not only adds to the existing evidence for the chelating power of niridazole with cations and its selective property in the process of ligation, but also suggests its value as a selective drug in copper storage diseases.

\section{References}

1. Salah. M. K.. Hammady, I. M., Hamad, M. Y. \& Abdel Aziz. F. T. (1970) Veterinärmed. Reihe A, 17, 257-260.

2. Abdel Aziz, F. T., Al-Mallah, A. K. \& Hassanein, R. R. (1976) Zentrbl. Veterinärmed. Reihe A, 23, 475-478.

3. Al-Khayat. T. M. N., Abdel Aziz, F. T., Izzat, N. N. \& Salah, M. (1978) J. Clin. Chem. Clin. Biochem. 16, 11-13.

4. Al-Khayat. T. M. N. \& Abdel Aziz, F. T. (1981) J. Clin. Chem. Clin. Biochem. 19, 21-23.

5. Abdel Aziz, F. T., Al-Tamer, Y. Y., Bashi, A. D. \& Abdel Rahim. S. (1982) J. Clin. Chem. Clin. Biochem. 20, 119-121.<smiles>NC1=CNC2C(Cl)NCCN12</smiles>

Fig. 1. Proposed structure of niridazole copper complex I. The copper content is $25.45 \%$. The molecular weight is 249.5 . It was prepared in vitro by mixing copper carbonate with niridazole in the presence of sodium metabisulphite.<smiles></smiles>

Fig. 2. Proposed structure of niridazole copper complex II. The copper content is $40.83 \%$. The molecular weight is 311 . It was prepared in vitro by mixing copper carbonate (double the amount in complex J) with the same amount of niridazole in the presence of sodium metabisulphite.

6. British Pharmaceutical Codex (1973). By Pharm. Press. Prepared in the Dept. of Pharm. Sciences of the Pharm. Society of Great Britain and published by direction of the Society's Council.

7. Hessel, D. W. (1968) Perkin-Elmer, Newsletter No. 7.

8. Abdel Aziz, F. T., Hiorm, P., Milburn, P. S., Smith, R. L. \& Williams, R. T. (1971) Biochem. J. 125. 25-26 P.

9. Abu El-Makarem, M. M., Milburn, P., Smith, R. T. \& Williams. R. T. (1967) Biochem. J. 105, 1289.

Professor F. T. Abdel Aziz

Dept. of Medical Biochemistry

College of Pharmacy

University of Zagazig

Zagazig

Egypt 
